ISSN: $1858-4837$

E-ISSN: 2598-019X

Volume 13, Nomor 1 (2018),

https:/jurnal.uns.ac.id/region

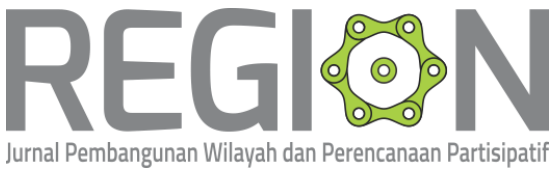

\title{
Keterhubungan Ruang Permukiman Tradisional Di Desa Sukarara Berlandaskan Nilai-Nilai Nyensek Dan Begawe
}

\section{Connectedness of Traditional Settlement Space in Sukarara Village Based on Nyensek and Begawe Value}

\author{
Sri Rahmi Yunianti ${ }^{a^{*}}$; Sudaryono ${ }^{b}$, Doddy Aditya Iskandar ${ }^{c}$ \\ aDepartemen Teknik Arsitektur dan Perencanaan, Fakultas Teknik, UGM \\ ${ }^{b}$ Departemen Teknik Arsitektur dan Perencanaan, Fakultas Teknik, UGM \\ 'Departemen Teknik Arsitektur dan Perencanaan, Fakultas Teknik, UGM, \\ *Email: rahmi.yunianti190693@gmail.com
}

\begin{abstract}
Abstrak
Desa Sukarara sebagai salah satu lokasi tujuan wisata kerajinan tenun di Kabupaten Lombok Tengah, telah mengalami perubahan fisik permukiman. Dari 6 jenis rumah tradisional yang pernah ada, saat ini tersisa 4 jenis rumah tradisional yang masih dipertahankan, namun bercampur dengan bangunan modern. Secara fisik, bangunan permukiman terlihat menggunakan elemen modern, namun secara tradisi dan tata cara aturan bermukim masyarakat memiliki keyakinan yang kuat pada nilai kosmologis. Fenomena antara perkembangan kehidupan masyarakat yang semakin modern dengan tetap melakukan tradisi dalam bermukim menjadi hal yang menarik untuk dikaji. Sehingga muncul pertanyaan yang ingin dikaji peneliti yaitu bagaimana konsep integrasi pola hunian masyarakat di permukiman tradisional Desa Sukarara. Tujuan penelitian ini ialah mendeskripsikan konsep integrasi pola hunian masyarakat di permukiman tradisional Desa Sukarara. Metode yang digunakan ialah induktif kualitatif, menggunakan pendekatan fenomenologi yang dalam tahapannya melalui proses grandtour, wawancara mendalam di desa Sukarara. Hasilnya ditemukan bahwa konsep integrasi dari pola permukiman tradisional yang ada di Desa Sukarara terbagi menjadi empat yakni: (1) bale beleq sebagai pembentuk ruang: keterhubungan sejarah; (2) alam sebagai petunjuk sakral bermukim: keterhubungan adat budaya; (3) ragam tipe dan bentuk rumah sebagai transformasi pola bermukim: keterhubungan fisik spasial; (4) bertani dan menenun sebagai basis hidup: keterhubungan sumber kehidupan. Keempat konsep tersebut, merubah orientasi pola permukiman tradisional yang disesuaikan masyarakat dengan aktifitas hidup yakni "nyensek" dan "begawe".
\end{abstract}

Kata Kunci: Integrasi, Pola Permukiman Tradisional, "Nyensek", "Begawe"

\begin{abstract}
Sukarara Village as one of tourism destination for handicraft weaving in Lombok Tengah Regency has changed, especially in settlement physic. There was six traditional house type but remain four types, which mixed with modern buildings. Physically, settlement building seen using modern element; however, the community has strong belief on cosmologic value, which implemented in settled rules and tradition. This study is to find out the connectedness in the phenomena between developments of an increasingly modern society with rules and tradition belief to settle; how integration and pattern formed in Sukarara Village. The objective of this reaseach is to describe concept of integration community of shelter pattern in Sukarara traditional settlement. This research used qualitative inductive method, which approached with phenomenology technique using in-depth interview in Sukarara Vilage. The result showed that there were four kinds of integration and pattern concept in Sukarara Village: (1) bale beleq as spatial
\end{abstract}


Sri Rahmi Yunianti dkk, Keterhubungan Ruang Permukiman...

shaping: connectedness history; (2) nature as sacred clue to settle: connectedness community culture; (3) various type and building shape as settlement pattern transformation: connectedness spatial physic; (4) farming and weaving as living basic: connectedness of source of life. The four concepts changed pattern orientation in traditional settlement, which is adapted by community along live activity, "nyensek" and "begawe".

Key Source : Integration, Traditional Settlement Pattern, "Nyensek", Begawe"

\section{PENDAHULUAN}

Permukiman tradisional sering direpresentasikan sebagai tempat yang masih memegang nilai-nilai adat dan budaya yang berhubungan dengan nilai kepercayaan atau agama yang bersifat khusus atau unik pada masyarakat tertentu yang berakar dari tempat tertentu di luar determinasi sejarah (Crysler, 2000 dalam Sasongko 2005). Pembentukan tata ruang permukiman sangat dipengaruhi oleh budaya masyarakatnya. Menurut Auliya (2009:120), pembentukan tata ruang permukiman sangat dipengaruhi oleh budaya masyarakat, hubungan tersebut membentuk garis korelasi yang sangat kuat, sehingga faktor perkembangan masyarakat sangat menentukan elemen permukimannya.

Desa Sukarara merupakan salah satu desa di Kabupaten Lombok Tengah, yang masih menjalankan tradisi budaya Sasak. Dari 127 desa di Kabupaten Lombok Tengah, Desa Sukarara menjadi satu-satunya desa yang masih banyak melakukan adat istiadat kebudayaan Sasak sesuai dengan aturan yang sebenarnya (Kepala desa Sukarara, 2017). Menilik runtutan sejarah, masyarakat asli desa Sukarara ialah keturunan dari Pujut. Dalam data Pranata Adat Nusa Tenggara Barat (NTB) tahun 2014, Pujut sendiri hingga saat ini disebutkan masih kental dengan nilai norma adat, dan masih tetap mempertahankan model perkawinan adat dan tradisi daur hidup, serta upacara kematian seuai dengan adat leluhurnya. Sehingga Desa Sukarara sebagai wilayah bagian dari keturuan Pujut, juga tetap menjalankan ritual dan acara adat. Dilakukan secara keseluruhan oleh sebagian besar masyarakat mulai dari anak-anak, remaja, dewasa hingga orang tua. Kegiatan adat dan daur hidup masyarakat sangat kental dengan nilai budaya, mulai dari ritual kelahiran, pernikahan, kematian hingga prosesi dalam pembentukan tata lingkungan permukiman dan rumah.

Keunikan lain dari Desa Sukarara yakni memiliki 6 jenis rumah tradisional dan 4 diantaranya masih dapat dilihat bentuk dan wujud aslinya hingga saat ini. Dalam penataan lingkungan permukiman dan pembangunan rumah, masyarakat Desa Sukarara masih melakukannya sesuai dengan aturan atau awiq-awiq yang berlaku, yakni sesuai dengan makna kosmologis sun (gording) yang harus 
Region, Vol. 13, No.1, Januari 2018: 80-94

menghadap Utara-Selatan ke arah Gunung Rinjanin, serta kesesuaian dengan alam yang diarahkan oleh petunjuk dari leluhur. Adanya permukiman tradisional yang bertahan ditengah-tengah perkembangan modernisasi zaman yang melingkupi sebagian besar permukiman di Kabupaten Lombok Tengah, menjadikan keunikan tersendiri dari Desa Sukarara.

Terdapat beberapa tradisi budaya lain yang masih tetap dijalankan masyarakat, seperti menenun kain khas Sasak yang dibuat secara manual dengan tangan dan alat sederhana. Kain ini biasa disebut dengan nama songket, proses pembuatan kain ini dinamakan dengan nyensek oleh masyarakat Sukarara. Kegiatan menenun ini dilakukan oleh hampir seluruh kaum perempuan di desa, sebagai rutinitas dan keseharian perempuan selain bekerja di sawah. Dahulu menenun ialah sebuah syarat atau aturan baku bagi wanita yang sudah dewasa untuk dapat menikah. Kemampuan menenun dianggap sebagai salah satu cara agar keluarga dapat bertahan hidup selain mengandalkan hasil dari pertanian, sebab hasil menenun dapat di barter dengan kebutuhan pokok masyarakat. Saat ini, menenun selain sebagai aktifitas hidup perempuan, juga sebagai salah satu lahan usaha masyarakat dengan menjual produk hasil tenun sebagai cendramata khas Lombok, menjadi fenomena lain dari desa Sukarara dibandingkan dengan desa-desa lain di Lombok Tengah.

Berkembangnya pariwisata di Pulau Lombok, meningkatkan pula perkembangan penjualan kerajinan tenun hingga dijadikannya Desa Sukarara sebagai salah satu tujuan wisata. Wilayah Desa Sukarara juga distimulasi sebagai tujuan wisata oleh pemerintah Kabupaten Lombok Tengah dengan berbagai promosi dan peningkatan prasarana yang ditujukan untuk mengakomodir desa Sukarara sebagai tujuan wisata kerajinan. Desa Sukarara juga dimasukkan dalam peraturan daerah Kabupaten Lombok Tengah dalam Rencana Tata Ruang Wilayah tahun 2011-2031 sebagai salah satu lokasi pengembangan wisata budaya dengan objek utama produk tenunan dan kampung tradisional.

Perubahan yang terjadi akibat kegiatan wisata yang semakin pesat, membuat sedikit perubahan pada cara hidup dan kebiasaan masyarakat. Pengaruh paling besar terlihat dari permukiman di desa Sukarara, dari karateristik utama bangunan yang dahulu sangat tradisional saat ini semakin modern serta orientasi masyarakat dalam memilih lokasi bermukim. Masyarakat yang memiliki kegiatan usaha dan kerajinan membentuk pola permukiman masyarakat dengan karakter linier mengikuti adanya prasarana yang mendorong kegiatan tersebut. Sedangkan 
Sri Rahmi Yunianti dkk, Keterhubungan Ruang Permukiman...

masyarakat yang sebagian besar menggeluti kegiatan pertanian, membentuk ruang permukiman di dalam lingkup kegiatan tersebut, membentuk pola ruang permukiman konsentris yang bedekatan dengan lahan pertanian. Terbentuknya kedua pola permukiman yang terjadi saat ini, tetap memiliki keterkaitan dengan aturan kosmologis yang berasal dari luluhur.

Pola terbentuknya permukiman di Desa Sukarara yang telah berubah orientasi berdasarkan beberapa aktifitas diatas, menjadi suatu hal yang perlu dikaji sebab hal ini tentu memberikan konsep bermukim masyarakat di Desa Sukarara yang berbeda dengan sebelumnya. Sehingga dari hal tersebut maka peneliti merasa penting untuk mengkaji bagaimana konsep bermukim dan pola hunian permukiman di Desa Sukarara, baik yang masih tradisional maupun yang telah berubah saat ini.

\section{METODE PENELITIAN}

\subsection{Pendekatan Penelitian}

Pendekatan penelitian yang dipergunakan dalam pelitian ini ialah pendekatan fenomenologi dengan metode induktif-kualititatif. Menurut Bogdan dan Taylor (1975:5 dalam Kaelan 2012) menjelaskan bahwa metode penelitin kualitatif adalah sebagai prosedur penelitian yang menghasilkan data deskriptif berupa kata-kata (bisa lisan untuk penelitian agama, sosial, budaya, filsafat), catatan yang berhubungan dengan makna, nilai serta pengertian. Model metode ini dalam pengamatan terhadap data penelitian tidak dibatasi dan diisolasi degan variabel, populasi, sampel, serta hipotesis.

Oleh karena itu, peneliti memposisikan diri observator dan subjek sistesis dari makna yang terlihat, terasa dan terjadi pada objek penelitian secara menyeluruh, tanpa membatasi dengan elemen dan aspek apapun, apa saja yang terlihat dilapangan menjadi temuan dan unit-unit informasi. Metode kualitatif senantiasa memiliki sifat holistik, yaitu penafsiran, terhadap data dalam hubungannnya dengan aspek yang mungkin ada.

Menurut Nasution (1992:11 dalam Musianto,2002) menjelaskan bahwa tujuan dari penelitian kualitatif bukanlah untuk menguji hipotesis yang didasarkan atas teori tertentu, melainkan untuk menemukan pola-pola yang mungkin dapat dikembangkan menjadi teori. Sesuatu yang ingin diacapai yaitu suatu pemahaman baru yang objektif dan inovatif dan dalam penelitian siosial budaya adalah teori 
Region, Vol. 13, No.1, Januari 2018: 80-94

grounded, yakni teori atau suatu pemahaman baru yang didasarkan atas hasil penelitian

Menurut Van Manen (2002 dalam Noor, 2010), fenomenologi merupakan sebuah tradisi pemikiran filosofis yang sangat berpengaruh yang telah melahirkan berbagai gerakan filosofis lainnya seperti : eksistensialisme, pascakulturalisme, postmodernisme, feminism, kritik kebudayaan dan berbagai bentuk teori baru. Selain itu, fenomenolog juga dianggap sebagai metode ilmu pengetahuan tentang manusia. Fenomenologi dinilai mampu untuk meneliti secara sangat reflektif hingga ke tingkatan makna yang terdalam dari manusia melalui pengalamannya.

Penggunaan pendekatan fenomenologi dalam penelitian ini, diharapkan akan mampu menguraikan bagaimana proses terjadinya perkembangan kehidupan sosial dan ekonomi yang mempengaruhi kondisi spasial permukiman tradisional Desa Sukarara. Sehingga data dan informasi yang akan diperoleh lebih valid berdasarkan pengalaman dan pengamatan di lapangan sesuai dengan kondisi masyarakat, melihat secara langsung dan mendeskripsikan apa yang terjadi dilapangan.

\subsection{Unit Amatan dan Unit Analisis}

Unit amatan dalam penelitian ini adalah kehidupan sosial, adat istiadat dan interaksi masyarakat dengan ruang di dalam permukiman tradisional di Desa Sukarara. Unit analisis berupa ruang interaksi sosial antar masyarakat sebagai pelaku di dalam permukiman tradisional.

\subsection{Sumber Data}

Sumber data dari penelitian ini menggunakan prosedur purposif. Menurut Botanri, 2016 prosedur pusposif adalah salah satu strategi menetukan informan yang paling umum dalam kualitiatif, yaitu menentukan kelompok peserta yang menjadi informan sesuai dengan kriteria terpilih yang relevan dengan masalah penelitian. Maka, dalam penelitian ini informan yang dianggap akan berperan banyak yakni tokoh adat, tokoh masyarakat, masyarakat penghuni permukiman tradisional dan masyarakat di sekitar kawasan permukiman tradisional.

\section{PEMBAHASAN}

\subsection{Sejarah Desa Sukarara}

Desa Sukarara menurut penuturan sesepuh berdiri sejak zaman penjajahan Belanda pada tahun 1755 terbentuk dari pecahan kecamatan Jonggat yang terbagi ke dalam dua wilayah yakni Jonggat Selatan dan Jonggat Utara. Pendiri Desa 
Sri Rahmi Yunianti dkk, Keterhubungan Ruang Permukiman...

Sukarara berasal dari Pujut yakni Raden Anugerah dan Raden Cempake, Raden Anugerah kemudian menjadi Kepala Adat yang ditunjuk oleh masyarakat, sedangkan Raden Cempake sebagai pengelola kegiatan pertanian desa.

Nama Sukarare diberikan oleh Raden Arute dengan makna "Suka" yang berarti senang, dan "Rare" yang berarti menerima dalam keadaan apapun. Hal ini mencerminkan wilayah Sukerare yang dalam keadaan apapun tetap senang menerima kondisi wilayahnya.

Sampai dengan saat ini, masyarakat Desa Sukarara masih berpegang teguh pada prinsip-prinsip tradisional warisan dari nenek moyang para penduduk, yang sampai saat ini masih berlaku dimasyarakat Desa Sukarara yaitu adat sopan santun yang dikenal di masyarakat Suku Sasak dengan Krama Desa (Profil Desa Sukarara dalam RPJMDesa tahun 2014-2018). Bagi masyarakat yang melanggar krama desa akan mendapatkan sangsi ringan berupa teguran dari tokoh adat sampai dengan sangsi sosial dari masyarakat.

\subsection{Kondisi Umum Desa}

1. Sumberdaya Alam

Pertanian merupakan sumberdaya alam terbesar di Desa Sukarara mencapai lebih dari $70 \%$ luasan wilayah desa, memliki luas wilayah 787,5 Ha, diantaranya lahan pertanian seluas $605 \mathrm{Ha}$, lahan permukiman seluas $137 \mathrm{Ha}$, lahan untuk fasilitas umum dan fasilitas sosial seluas 45,5 Ha (RPJM Desa Sukarara, 2014-2018). Dominasi lahan pertanian di Desa Sukarara ini sebagai sumber mata pencaharian utama masyarakat baik untuk tanaman semusim seperti padi dan palawija.

2. Sumberdaya Manusia

Berdasarkan data Badan Pusat Statistik tahun 2016, secara umum jumlah penduduk Desa Sukarara mencapai 8.758 jiwa dengan jumlah penduduk lakilaki secara signifikan lebih sedikit dibandingkan dengan jumlah penduduk perempuan. Dimana perbedaan jumlahnya yakni 4.101 jiwa penduduk laki-laki dan jumlah penduduk perempuan sebanyak 4.657 jiwa dengan jumlah rumah tangga sebanyak $3.147 \mathrm{KK}$ dengan jumlah rata-rata aggota dalam rumah tangga sebanyak 3 orang.

Mata pencaharian utama masyarakat pun lebih didominasi sebagai petani dan buruh tani dengan jumlah 3.032 jiwa sebagai petani dan 1.863 jiwa sebagai buruh tani. Selanjutnya diikuti oleh pekerjaan sebagai pengerajin dengan jumlah 2.805 jiwa yang terdiri dari penduduk wanita usia produktif hingga 
Region, Vol. 13, No.1, Januari 2018: 80-94

nonproduktif atau dari anak usia sekolah dasar hingga perempuan monopose. Hal ini menunjukkan bahwa rata-rata masyarakat di Desa Sukarara sangat giat dalam mengelola dan memanfaatkan sumberdaya alam dan budaya yang ada untuk dijadikan sebagai penghidupan sehari-hari.

3. Adat dan Tradisi

a. Acara Adat

Saat ini kegiatan budaya yang masih dilaksanakan oleh masyarakat desa Sukarara dalam kegiatan budaya dan tradisi yakni upacara pernikahan (merarik), upacara kematian, dan upacara khitanan (suanatan). Ketiga upacara ini dilakukan harus dilakukan masyarakat sesuai dengan tata cara yang berlaku dimasyarakat berdasarkan arahan dari pemuka adat (kiyai). Rangkaian upacara ini dilakukan oleh masyarakat secara bergotong royong dan melibatkan kelompok-kelompok banjar di tiap dusun untuk membantu dalam proses pelaksanaan acara.

b. Atraksi Seni

Atraksi seni dan budaya yang terdapat di Desa Sukarara berupa kesenian tradisional dan Gendang Beleq, Colokak, Ponggokan, Nyongkolan. Jenis atraksi budaya tersebut hanya bisa dinikmati ketika berlangsungnya acara adat seperti begawe Sorong Serah Ajikrame dan begawe Nyunatan yang diselenggarakan oleh masyarakat dengan lembaga adat untuk memeriahkan acara adat pernikahan dan sunatan.

c. Menenun

Kaum peremuan di Desa Sukarara diajarkan untuk mengenal dan mempelajari bagaimana proses pembuatan kain tenun semenjak kecil yang dikerjakan dengan tangan secara manual. Tujuannya ialah selain mengenalkan tradisi leluhur, juga sebagai cara yang diterapkan oleh orang tua kepada anak perempuan agar dapat hidup dengan terampil dan cekatan, sehingga ketika dewasa nanti anak gadis sudah mampu menghidupi dirinya dengan bekal yang jelas.

Selain itu, aturan adat yang dahulu menetapkan bahwa gadis belum boleh untuk menikah jika belum bisa membuat kain tenun songket. Dahulu, hal tersebut diterapkan dengan tujuan supaya perempuan yang telah menikah tersebut dapat memberikan tambahan pemasukan penghasilan bagi suami yang bekerja di sawah atau ladang, dengan cara menukarkan hasil kain songket tersebut dengan bahan makanan kepada warga masyarakat lainnya. Namun, 
Sri Rahmi Yunianti dkk, Keterhubungan Ruang Permukiman...

tradisi tersebut saat ini hampir tidak menjadi larangan bagi perempuan di desa Sukarara unutuk menikah. Mengingat sumber penghidupan lain dapat menjadi pemenuhan kehidupan keseharian masyarakat, yang terjadi saat ini ialah perempuan di desa Sukarara lebih menjadikan kemampuan menenun sebagai usaha mandiri untuk keluarga.

\subsection{Kondisi Permukiman}

Saat ini, masih terdapat beberapa rumah tradisional di desa Sukarara ini yang berusia ratusan tahun, di dusun Batu Entek, dusun Blong Daye dan dusun Ketangga. Rumah tersebut merupakan rumah peninggalan nenek moyang, sampai saat ini keberadaan rumah tersebut masih dijaga oleh keturunan pemuka adat tersebut. Selain itu, rumah-rumah di permukiman masyarakat juga tmasih banyak yang berbentuk rumah tradisional.

Rumah tradisional yang terdapat di permukiman desa Sukarara terklasifikasi menjadi 6 bentuk, yakni bale tani; bale bonter; bale kodong; bale lompak; bale jajar; dan bale tajuk yang memiliki makna dan filosofi yang berbeda dalam setiap rumah. Rumah-rumah di Desa Sukarara dalam pembentukannya memiliki tata cara dan ritual tersendiri, diantaranya yakni arah gording atau dalam bahasa Sukarara disebun sun yakni kayu penyangga utama atap yang harus menghadap ke UtaraSelatan, mengarah ke Gunung Rinjani. Diantara, rumah-rumah tradisional tersebut, masih ada 4 bale yang dapat dilihat desa Sukarara yakni bale tani, bale lompak, bale kodong dan bale bonter. Saat ini, dalam setiap lingkungan permukiman di desa Sukarara antara rumah tradisional telah bercampur dengan rumah modern, namun tetap mengedepankan tata cara dan ritual bermukim yang sama seperti aturan yang ada.

\subsection{Perubahan Cara Bermukim Masyarakat}

Perubahan cara bermukim masyarakat Desa Sukarara, sudah mulai terjadi sekitar tahun 75-an saat pemerintahan presiden Soeharto. Perubahan mulai terjadi ketika lahan pertanian masyarakat yang sebagian menanam alang-alang untuk atap bale, dirubah secara keseluruhan menjadi pertanian padi. Akhirnya kelangkaan untuk mengganti bahan atap pun terjadi. Masyarakat pun sudah banyak melakukan pekerjaan di luar wilayah lain selain bertani, sehingga kemampuan untuk mengganti bahan bangunan rumah menjadi makin baik. 


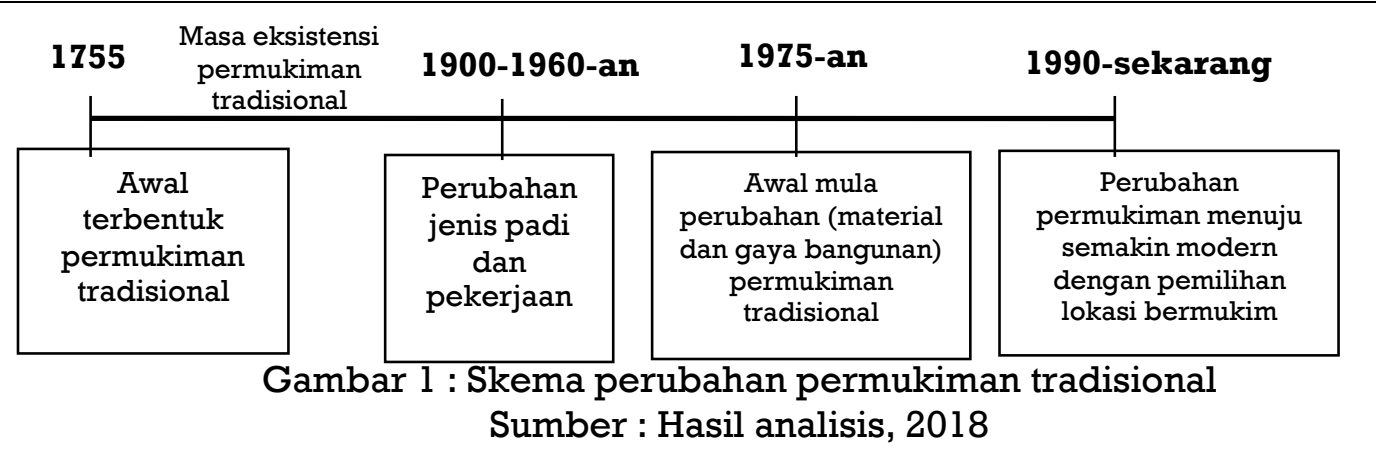

Perubahan perkembangan wilayah Sukarara menjadi semakin baik ketika tahun 80-an masyarakat mulai mengusahakan kerajinan tenun sebagai produk yang diperjual belikan secara luas. Sehingga perkembangan permukiman masyarakat mulai mendukung kegiatan tersebut dengan merubah rumah menjadi toko atau artshop. Hingga saat ini jumlah artshop lebih dari 15 unit dengan lokasi yang berada disepanjang jalan utama Desa Sukara.

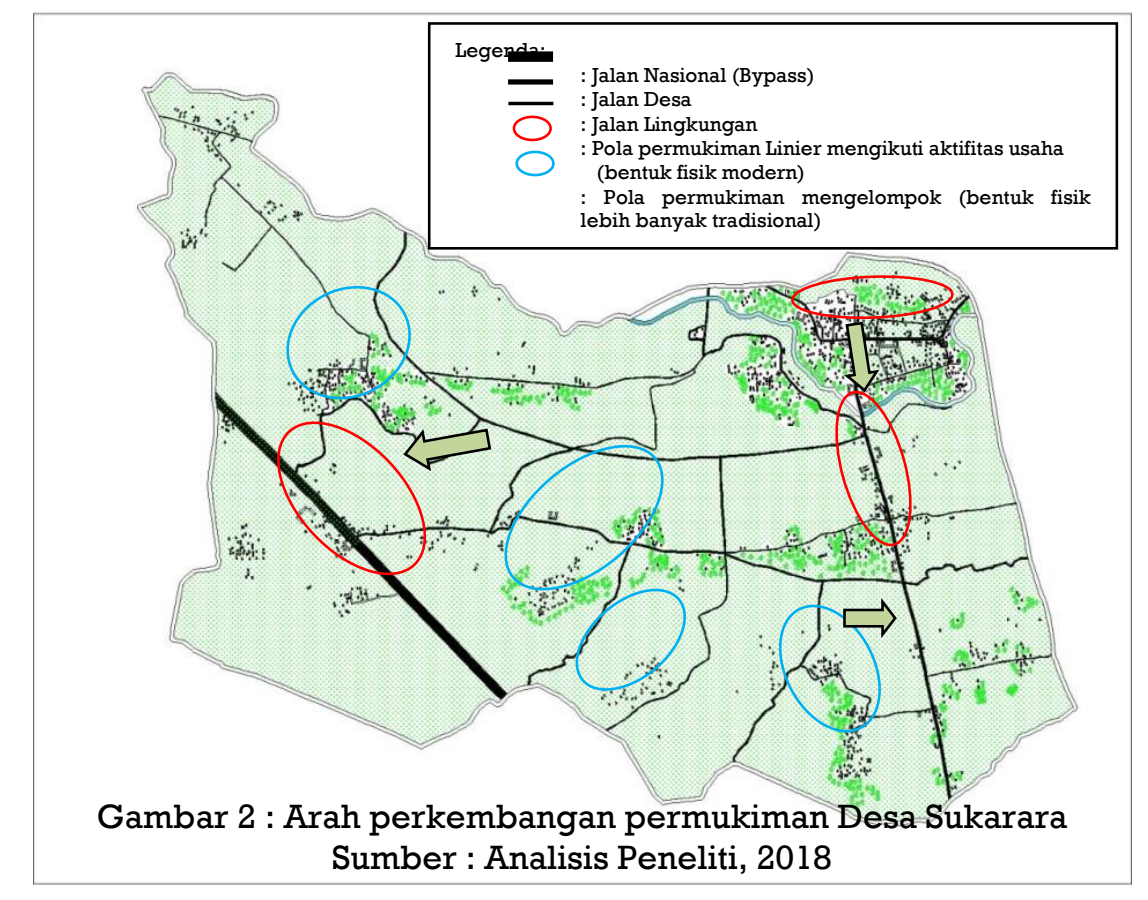

Perubahan pola bermukim masyarakat di permukiman tradisional Desa Sukarara, membentuk konsep-konsep ruang permukiman yang dijabarkan sebagai berikut :

\section{Bale beleq Sebagai Pembentuk Ruang : Keterhubungan Sejarah}

Bale beleq merupakan sebuah rumah tradisional dengan bentuk bale tani yang saat ini dijadikan sebagai tempat suci bagi masyarakat Desa Sukarara, tidak semua orang dapat memasuki rumah ini. Terdapat tiga hubungan yang membentuk Bale Beleq sebagai pembentuk ruang permukiman di Desa Sukarara yakni (1) 
Sri Rahmi Yunianti dkk, Keterhubungan Ruang Permukiman...

hubungan hunian di sekitar bale beleq dengan permukiman yang tersebar di dusun-dusun lainnya, (2) hubungan antara fungsi bale beleq dengan kehidupan masyarakat, dan (3) hubungan kekerabatan masyarakat di permukiman sekitar bale beleq dengan permukiman yang tersebar di dalam dusun-dusun.

Bale beleq sebagai rumah pertama merupakan awal perkembangan permukiman di Desa Sukarara, lokasi pertama bale beleq berada di dusun Blong Daye dihuni oleh keturunan dan keluarga dari pemimpin adat Raden Anugerah dan Raden Cempake. Dari lingkungan ini kemudian berkembang permukiman di dusun Ketangga Bunsambang, dan dusun Buncalang yang masih memiliki hubungan keluarga. Proses pembentukan rumah pertama kali ini menjadi awal bagaimana bale beleq sebagai pembentuk ruang bermukim masyarakat sekitar, pun demikian dengan tata cara pengaturan bangunan dan lingkungan permukiman yang saat ini diterapkan oleh masyarakat semua di dusun-dusun berpatokan pada bale beleq. Saat ini, bale beleq merupakan tempat yang sakral bagi masyarakat dan sebagai situs peninggalan bersejarah, sehingga masyarakat setiap tahun dalam kalender sasak melakukan ritual atau acara pembersihan rumah sekaligus benda-benda pusaka peninggalan nenek moyang. Tetua adat, tokoh desa dan masyarakat biasa tetap melaksanakan kegiatan pembersihan bale beleq. Adanya bale beleq membentuk ruang religi dan sosial masyarakat, untuk mengingat sejarah dengan kegiatan yang setiap tahun dilakukan berupa acara adat.

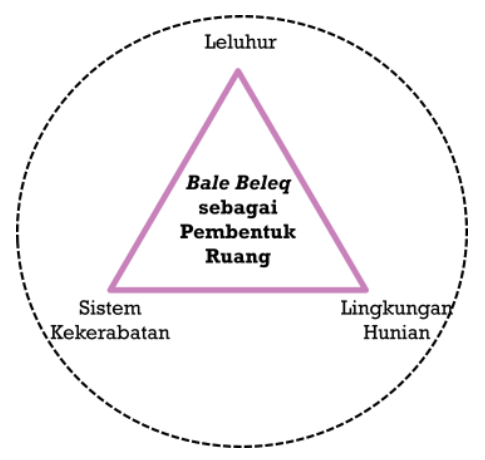

Gambar 3. Skema Keterhubungan Konsep Bale Beleq Sebagai Pembentuk Ruang : Keterhubungan Sejarah Sumber : Hasil Analisis Peneliti, 2018

\section{Ragam Tipe dan Bentuk Rumah sebagai Transformasi Pola Bermukim :}

\section{Keterhubungan Fisik Spasial}

Ada tiga hubungan besar yang terlihat dalam konsep ini yakni (1) hubungan perubahan tipologi rumah, (2) hubungan tata letak bangunan dan lingkungan hunian, (3) hubungan sebaran dan cara bermukim. Perubahan karakteristik rumah masyarakat yang terjadi di Desa Sukarara saat ini, merupakan sebuah bentuk 
Region, Vol. 13, No.1, Januari 2018: 80-94

ikutnya masyarakat dalam perkembangan zaman yang ada, namun perubahan yang terjadi tidak membuat masyarakat mengenyampingkan tatanan dan ritual pembangunan rumah yang ada. Masyarakat menerima perubahan yang ada dalam tiap lingkungan, serta perubahan orientasi pemilihan masyarakat dalam bermukim sesuai dengan kondisi dan aktifitas masyarakat. Peraturan mengenai cara pembangunan secara fisik memang sudah tidak diatur sedemikian rupa seperti yang terjadi pada kondisi permukiman tradisional dahulu, hanya saja masyarakat secara naluri mempercayai dengan nilai-nilai luhur yang akan mempengaruhi kehidupan dengan menjalankan tradisi bermukim yang lama.

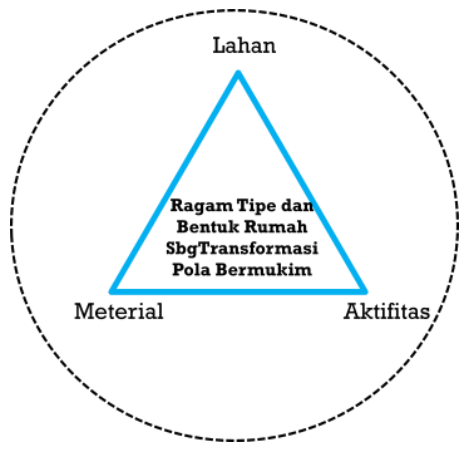

Gambar 4. Skema Keterhubungan Konsep Ragam Tipe dan Bentuk Rumah sebagai Transformasi Pola Bermukim : Keterhubungan Fisik Spasial

Sumber : Hasil Analisis Peneliti, 2018

\section{Alam sebagai Petunjuk Sakral Bermukim : Keterhubungan Adat Budaya}

Keyakinan masyarakat terhadap nilai luhur dan kosmologis dalam bermukim ditunjukkan masyarakat dalam tatanan dan ritual yang dilakukan ketika akan membangun rumah. Dengan landasan tersebut terbentuk dua hubungan yang erat terkait landasan masyarakat Sukarara dalam bermukim yakni (1) hubungan kosmologi dan landasan membangun rumah, dan (2) hubungan adat dan ritual membangun rumah. Landasan utama masyarakat dalam bermukim sejak dahulu yakni mengikuti arah nilai yang berasal dari alam, yang menghadapkan sun (gording) atau kayu penyangga utama atap rumah ke arah Utara-Selatan menghadap Gunung Rinjani. Nilai kosmologis ini lalu menjadikan setiap elemen ruang dalam rumah dan di lingkungan memiliki hubungan yang sangat dekat dengan kehidupan yang dijalani masyakat. Nilai ini sangat sakral dan penting untuk diingat bagi seluruh masyarakat, sehingga setiap segala bentuk aktifitas yang dilakukan masyarakat akan mengarah pada nilai tersebut, terutama dalam hal tatanan bermukim dan tradisi budaya. 


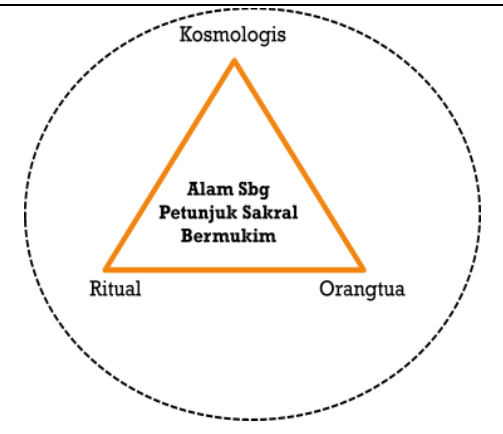

Gambar 5. Skema Keterhubungan Konsep Alam sebagai Petunjuk Sakral Bermukim :

Keterhubungan Adat Budaya

Sumber : Hasil Analisis Peneliti, 2018

\section{Bertani dan Menenun sebagai Basis Hidup : Keterhubungan Sumber Kehidupan}

Lahan pertanian yang mendominasi wilayah Desa Sukarara, menjadikan bertani sebagai profesi utama masyarakat. Sehingga konsep ini menjadi terlihat berhubungan dengan pola bermukim masyarakat, maka dijabarkan ke dalam beberapa hubungan yakni: (1) hubungan aktifitas tenun dengan pola bermukim masyarakat; (2) hubungan aktifitas pertanian dengan pola bermukim masyarakat; (3) hubungan prasarana dengan pola kegiatan ekonomi dan pola bermukim masyarakat.

Bertani tidak dapat dipisahkan dari kehidupan masyarakat desa Sukarara, walaupun masyarakat telah memiliki pekerjaan di luar pertanian namun sebagian besar hasil dari pekerjaan tersebut akan diinvestasikan kembali pada lahan pertanian sebagai modal untuk kehidupan. Dari pengembangan pertanian, pengembangan permukiman masyarakat pada kawasan pertanian tetap terus tejadi di Desa Sukarara. Masyarakat Sukarara, lebih cenderung memilih bermukim pada lokasi yang dekat dengan permukiman, walaupun jauh dari aksibilitas. Masyarakat akan lebih nyaman tinggal dekat dengan sumber kehidupan.

Selain pertanian, masyarakat sedang giat dalam berusaha dalam pengembangan kerajinan tenun, hal ini ditunjukkan dengan makin banyaknya sarana usaha yang mendukung kegiatan tersebut dengan datangnya wisatawan yang semakin banyak di desa Sukarara sebagai tujuan belanja kerajinan khas Lombok.

Usaha tenun ini terlihat sebagai kegiatan yang sangat merubah fisik pembangunan di Desa Sukarara, sarana penunjang kegiatan dan perbaikan askes demi pengembangan usaha juga diwadahi oleh pemerintah. Sehingga dengan demikian masyarakat secara tidak langsung terpacu untuk mengembangkan usaha dibidang ini. 


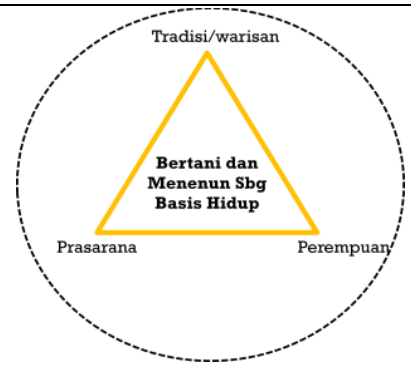

Gambar 6. Skema Keterhubungan Konsep Bertani dan Menenun sebagai Basis Hidup : Keterhubungan Sumber Kehidupan Sumber : Hasil Analisis Peneliti, 2018

\section{Teorisasi Keterhubungan Ruang Permukiman Tradisional di Desa Sukarara}

\section{Berlandaskan Nilai-Nilai Nyensek dan Begawe}

Dari beberapa konsepsi yang telah dilakukan, bahwa terdapat dua nilai yang masih berkembang pada permukiman tradisional di Desa Sukarara. Nilai-nilai tersebut yakni nilai sakral (yang bersifat suci) dan nilai profan (nilai bersifat duniawi). Nilai sakral terlihat dari tetap berlakunya tatanan kosmologis dan tata cara atau ritual yang dilakukan masyarakat dalam proses bermukim. Nilai ini termuat dalam dua hubungan konsep besar, yakni bale beleq sebagai pembentuk ruang sebagai bentuk keterhubungan sejarah bermukim masyarakat dan alam sebagai petunjuk sakral bermukim sebagai keterhubungan adat budaya masyarakat dalam bermukim.

Sedangkan nilai profan, terlihat dari masuknya perkembangan modern yang menyebabkan perubahan pada fisik bangunan permukiman dan perubahan pola pikir masyarakat dalam orientasi pemilihan lokasi bermukim yang terkait dengan aktifitas modern (usaha-usaha). Nilai ini termuat dalam dua hubungan konsep berikutnya yakni ragam tipe dan bentuk rumah sebagai transformasi pola bermukim sebegai bentu keterhubungan fisik spasial, serta konsep bertani dan menenun sebagai basis hidup sebagai bentuk keterhubungan sumber kehidupan masyarakat.

Dalam hal ini, nyensek dan begawe merupakan nilai lokal ini akan selalu berkembang di masyarakat sebagai sebuh tradisi yang akan tetap dijaga oleh masyarakat hingga kapan pun, walaupun akan terjadi perkembangan zaman yang berubah-ubah. Tradisi ini juga sebagai suatu aktifitas yang menghubungkan segala macam tatanan hidup masyarakat termasuk dalam bermukim. Nilai tersebut dijadikan sebagai teori lokal pembentuk keterhubungan dan proses perubahan pada pola permukiman masyarakat d Desa Sukarara, disebabkan aktifitas ini menjadi pembentuk aktifitas hidup masyarakat yang berkembang saat ini. Nyensek 
Sri Rahmi Yunianti dkk, Keterhubungan Ruang Permukiman...

sendiri berarti menenun, dan begawe merupakan acara adat berupa pesta besar yang menjadi ruang berkumpul masyarakat dalam acara tradisi masyarakat.

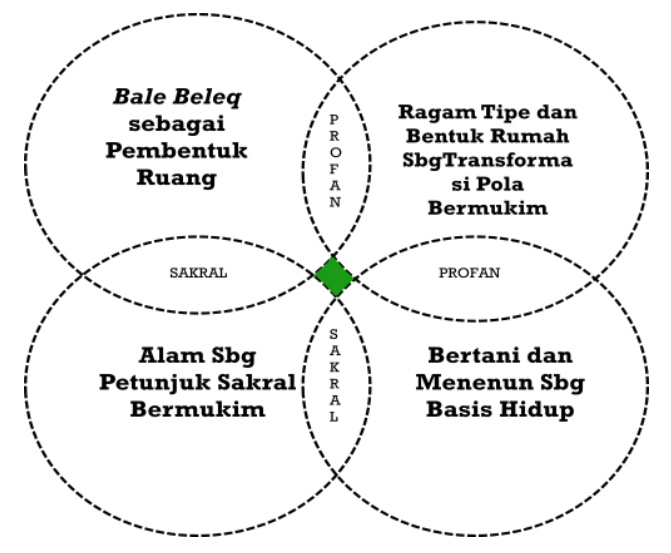

: Keterhubungan
Ruang
Permukiman
Tradisional
Berlandaskan
Nilai-Nilai
Nyensek dan
Begawe

Gambar 7. Keterhubungan Konsep dengan Nilai Nyensek dan Begawe Sumber : Hasil Analisis Peneliti, 2018

\section{KESIMPULAN}

Konsep pola bermukim masyarakat di permukiman tradisional Desa Sukarara, membentuk nilai sakral dan profan yang seiring sejalan dalam tatanan kehidupan masyarakat. Nilai-nilai ini menjadi dasar dalam aktifitas hidup dan aktifitas sosial masyarakat, yang sangat besar kaitannya dengan nyensek dan begawe sebagai pembentuk ruang permukiman dan kehidupan masyarakatdi Desa Sukarara.

Dalam tatanan empiris pola permukiman tradisional di Desa Sukarara terbentuk menjadi dua, yakni: (1) Pola permukiman linier dengan kecenderungannya mengikuti aktifitas dan usaha baru yang dijalani masyarakat yakni mendekati pusat kegiatan di desa. Pada pola ini perubahan fisik bangunan sangat terlihat mengikuti perkembangan zaman, namun tetap mengedepankan nilai kosmologis dalam pembangunan rumah; (2) Pola permukiman mengelompok mengikuti mata pencaharian bertani, dengan bentuk fisik bangunan yang masih banyak mempertahankan nilai kesakralan. 


\section{REFERENSI}

Auliya, Tody, dkk. 2009. Permukiman Tradisional Suku Sasak Di Dusun Senaru. ejournal Arsitektur Volume 2 Nomor 2. Jurusan Perencanaan Wilayah dan Kota Fakultas Teknik Universitas Brawijaya. Malang.

Botanri, Adnan. 2016. Kebertahan Permukiman Nelayan Terpencil di Dusun Wael Kabupaten Seram Bagian Barat Provinsi Maluku. Tesis. MPKD UGM. Yogyakarta.

Kaelan. 2012. Metode Penelitian Kualitatif Interdisipliner. Paradigma. Yogyakarta.

Musianto, Lukas. Perbedaan Pendekatan Kuantitatif dengan Pendekatan Kualitatif dalam Metode Penelitian. Jurnal Manajemen dan Kewirausahaan, Vol. 4, No. 2, September 2002. Jurusan Ekonomi Manajemen, Fakultas Ekonomi Universitas Kristen Petra. Surabaya.

Noor, Bani M. 2010. Fenomenologi Arsitektur. Koleksi Khusus Metodologi Penelitian. Jurusan Teknik Arsitektur dan Perencanaan FT UGM. Yogyakarta.

\section{REFERENSI LAIN}

BPS. 2012-2017. Kecamatan Jonggat Dalam Angka. BPS Kabupaten Lombok Tengah. RPJM Desa Sukrara tahun 2014-2018

RTRW Kabupaten Lombok Tengah 2011-2031.

Pranata Daftar Inventarisasi Komunitas Adat NTB. 2014. Nama Komunitas Adat yang Ada di Kabupaten Kota di Nusa Tenggara Barat. https://pranataadatntb.wordpress.com/2016/07/25/first-blog-post/\#more-6 diakses 8 Januari 2018 